\title{
New records of guano-associated minerals from caves in northwestern Borneo
}

\author{
Donald A. McFarlane ${ }^{1^{*}}$ and Joyce Lundberg ${ }^{2}$ \\ ${ }^{1}$ Keck Science Center, The Claremont Colleges, Claremont, CA 91711, USA \\ ${ }^{2}$ Department of Geography and Environmental Studies, Carleton University, Ottawa, ON K1S 5B6, Canada
}

\begin{abstract}
Recent studies of ancient bat guano deposits in the caves of Gunung Mulu National Park and Niah National Park, Sarawak, Malaysia, have resulted in noteworthy records of phosphate minerals from these environments, including variscite, nano-particulate silica, fluorapatite, and niter.
\end{abstract}

Keywords: $\quad$ Niah, Gunung Mulu, Niter, Fluorapatite, Variscite

Received 15 December 2017; Revised 24 January 2018; Accepted 10 February 2018

Citation: McFarlane D.A. and Lundberg J., 2018. New records of guano-associated minerals from caves in northwestern Borneo. International Journal of Speleology, 47 (2), 119-126. Tampa, FL (USA) ISSN 0392-6672 https://doi.org/10.5038/1827-806X.47.2.2169

\section{INTRODUCTION}

In tropical caves, some insectivorous bat species can form very large colonies that deposit huge quantities of guano over extended periods of time. These accumulations can reach tens of thousands of cubic meters in volume (Peck \& Kukalova-Peck, 1981), 10 m or more in depth, and incorporate material dating back more than 50,000 years (Bird et al., 2007). In wet or moist conditions, guano decomposition can be rapid and the products of decomposition are often removed by percolating water. Conversely, under very dry conditions, bat guano may be preserved with little or no diagenesis over thousands of years (e.g., Wurster et al., 2010a). Over appropriate timescales, these deposits may generate a range of diagenetic nitrate, phosphate and sulfate minerals within a stratified, organic- rich sequence (Shahack-Gross et al., 2004; Pogson et al., 2014). Here we report on two phosphatic mineral species of distinctive appearance associated with bat guano diagenesis in caves of northwestern Borneo.

\section{MATERIALS AND METHODS}

Samples were taken from two caves in Sarawak, northwestern Borneo: Racer Cave (4.056 N, 114.827 E), Mulu National Park, and Niah Cave (3.816 N; 113.781 E), Niah National Park. Mineral composition and morphology was identified using X-ray diffraction (XRD;
Attard Laboratories, San Diego, CA, US), and scanning electron microscopy (SEM) and energy dispersive X-ray spectroscopy (EDS) at the Nano-imaging Facility of Carleton University, Ottawa, Canada.

\section{RESULTS}

\section{Racer Cave (Variscite and nano-particulate Silica)}

Racer Cave preserves several exposures of a distinctive, pink-colored mineral that has developed as an efflorescence, in association with a white powdery material, on allochthonous cave guano (Fig. 1A, B). The pink phosphate exists as a thin crust (generally less than $1 \mathrm{~mm}$ in thickness) on the white material which proved to be silica (details below).

XRD spectral analysis on the pink mineral and automatic software identification suggests that it is a complex phosphate, dominated by variscite,
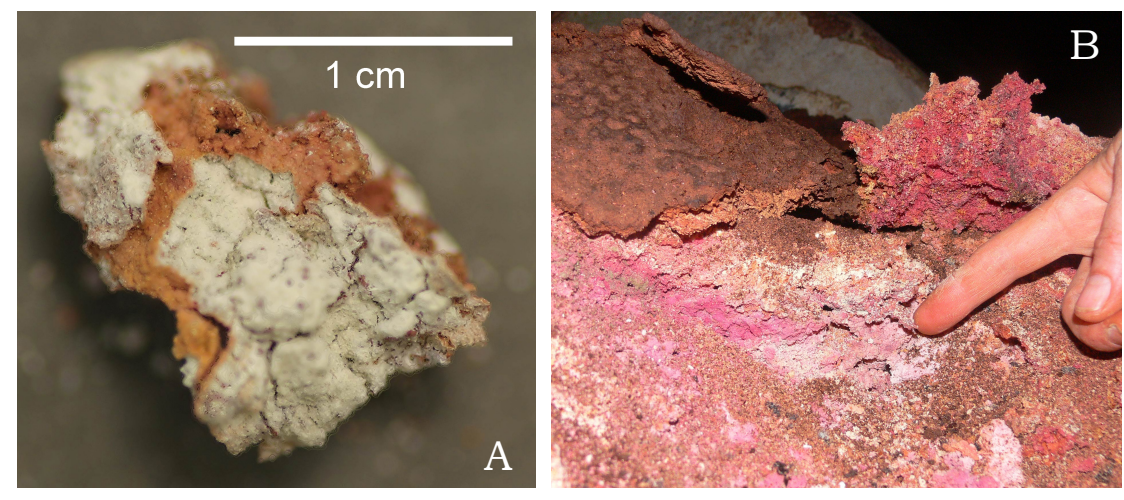

Fig. 1. Racer Cave phosphate: the pink material, revealed when the surface crust is peeled back, is variscite; the white powdery material is nano-particulate silica; and the pale-brown underlying material is guano. A) Macro view; B) General view. 


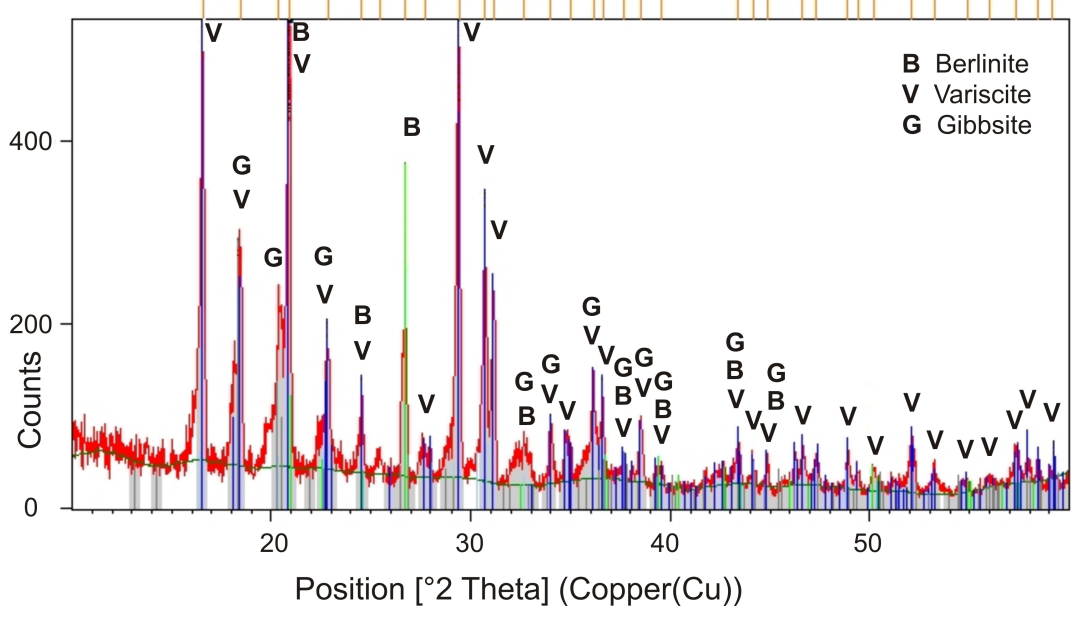

Fig. 2. XRD spectrum from the Racer Cave phosphate.

$\mathrm{AlPO}_{4} \cdot 2 \mathrm{H}_{2} \mathrm{O}$, but with some gibbsite, $\mathrm{Al}(\mathrm{OH})_{3}$, and berlinite, $\mathrm{AlPO}_{4}$ (Fig. 2, Table 1). The semi-quantitative result indicates approximately $76 \%$ variscite, $13 \%$ gibbsite, and $11 \%$ berlinite. Note that the software did not identify any quartz in this material. The berlinite peak at $26.70^{\circ} 2 \theta$, standing out clearly from the

Table 1. XRD data for Racer Cave phosphate.

\begin{tabular}{|c|c|c|c|c|}
\hline Pos. $\left.{ }^{\circ} \mathbf{2} \boldsymbol{\theta}\right]$ & $\begin{array}{c}\text { Height } \\
\text { [cts] }\end{array}$ & $\begin{array}{c}\text { FWHM } \\
\text { Left [ } \mathbf{2} \boldsymbol{\mathbf { \theta }} \text { ] }\end{array}$ & $\begin{array}{c}\text { d-spacing } \\
{[\mathbf{A}]}\end{array}$ & $\begin{array}{c}\text { Rel. Int. } \\
{[\%]}\end{array}$ \\
\hline 16.59 & 465.70 & 0.1968 & 5.344 & 100.00 \\
\hline 18.47 & 211.33 & 0.1378 & 4.804 & 45.38 \\
\hline 20.35 & 162.25 & 0.2362 & 4.365 & 34.84 \\
\hline 20.92 & 435.59 & 0.1181 & 4.247 & 93.53 \\
\hline 22.84 & 125.67 & 0.1968 & 3.894 & 26.99 \\
\hline 24.53 & 81.79 & 0.1574 & 3.630 & 17.56 \\
\hline 25.47 & 17.66 & 0.3149 & 3.497 & 3.79 \\
\hline 26.70 & 213.82 & 0.1181 & 3.339 & 45.91 \\
\hline 27.71 & 28.74 & 0.4723 & 3.219 & 6.17 \\
\hline 29.41 & 446.60 & 0.2165 & 3.037 & 95.90 \\
\hline 30.69 & 280.02 & 0.1181 & 2.914 & 60.13 \\
\hline 31.15 & 209.77 & 0.1574 & 2.871 & 45.04 \\
\hline 32.69 & 45.85 & 0.4723 & 2.739 & 9.85 \\
\hline 34.02 & 55.34 & 0.1968 & 2.636 & 11.88 \\
\hline 35.02 & 31.44 & 0.3542 & 2.562 & 6.75 \\
\hline 36.13 & 107.65 & 0.1968 & 2.486 & 23.12 \\
\hline 36.61 & 88.44 & 0.1378 & 2.455 & 18.99 \\
\hline 37.67 & 21.15 & 0.2362 & 2.388 & 4.54 \\
\hline 38.54 & 71.82 & 0.1574 & 2.336 & 15.42 \\
\hline 39.52 & 18.35 & 0.3936 & 2.281 & 3.94 \\
\hline 43.43 & 49.33 & 0.1574 & 2.084 & 10.59 \\
\hline 44.15 & 25.81 & 0.1574 & 2.051 & 5.54 \\
\hline 44.87 & 25.44 & 0.1968 & 2.020 & 5.46 \\
\hline 46.64 & 40.56 & 0.1968 & 1.948 & 8.71 \\
\hline 47.32 & 31.69 & 0.2362 & 1.921 & 6.81 \\
\hline 48.90 & 37.18 & 0.1574 & 1.863 & 7.98 \\
\hline 49.39 & 21.53 & 0.2362 & 1.845 & 4.62 \\
\hline 50.21 & 22.32 & 0.1968 & 1.817 & 4.79 \\
\hline 52.11 & 62.24 & 0.2755 & 1.755 & 13.37 \\
\hline 53.24 & 22.54 & 0.3149 & 1.721 & 4.84 \\
\hline 54.87 & 11.84 & 0.5510 & 1.673 & 2.54 \\
\hline 56.01 & 8.39 & 0.4723 & 1.642 & 1.80 \\
\hline 57.34 & 35.30 & 0.2362 & 1.607 & 7.58 \\
\hline 58.42 & 19.11 & 0.1968 & 1.580 & 4.10 \\
\hline 59.15 & 7.30 & 0.3149 & 1.562 & 1.57 \\
\hline
\end{tabular}

two gibbsite peaks to either side, cannot be confused with a quartz peak, expected at $26.65^{\circ} 2 \theta$, and this material also does not have the other quartz peaks expected at 20.85, 36.54, and $40.29^{\circ} 2 \theta$ (Morris et al., 1981).

At the micro-scale, the variscite crust is revealed to have an external morphology that is botryoidal, with globules of $\sim 100$ 300 microns diameter (Fig. 3A, B). EDS on the surface of the crust confirmed that it is composed of variscite. The orthorhombic dipyramidal crystal structure of variscite (http://webmineral.com \data \Variscite. shtml) is here modified by the packing of crystallites (Fig. 3C). Internally, each globule can be seen to be made up of radiating blades

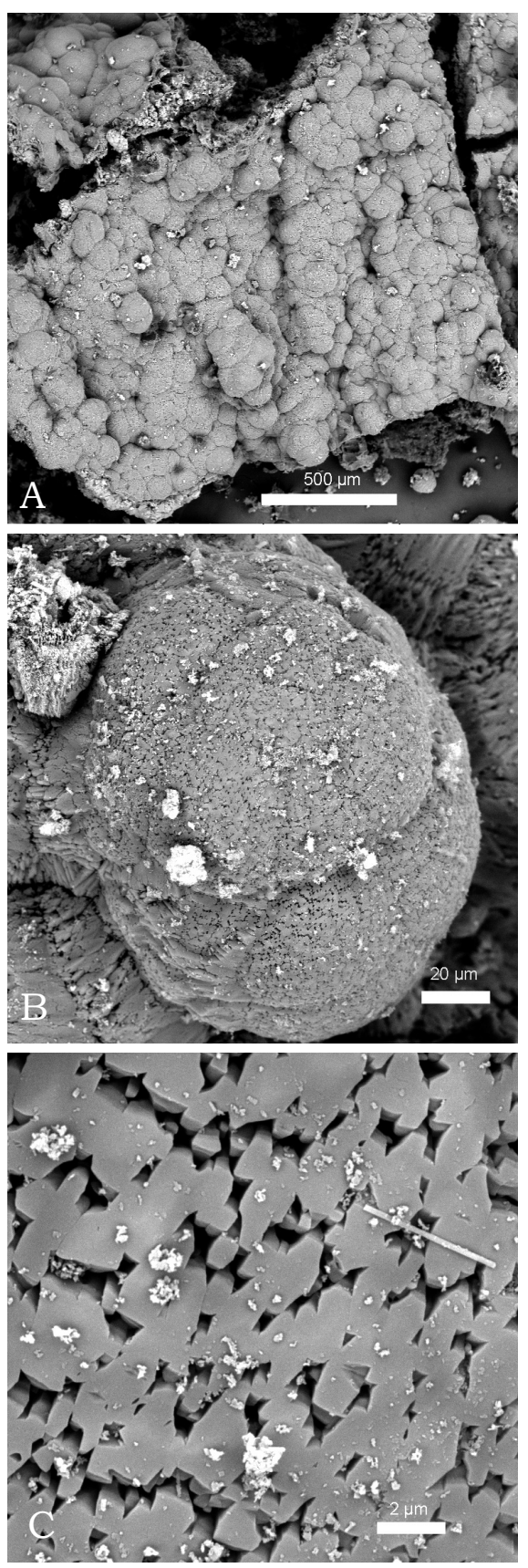

Fig. 3. SEM of Racer Cave variscite crust viewed from above. A) Botryoidal morphology of crust; B) View of single globule; C) Detail of globule surface showing crystallite packing and intercrystallite gaps -the orthorhombic dipyramidal crystal structure is greatly modified by packing of crystallites. 
(Fig. 4A, B) in what appears to be a druzy or spherulitic structure. Some of these show modifications that suggest stages in the alteration/erosion of variscite. Viewed from above, some blade edges are corroded and inter-crystallite spaces concomitantly increased (Fig. 5A); internally, especially towards the centers of the spherules, the bladed/platy structures show more-or-less chattering of the edges, in the vicinity of randomly-shaped powdery detritus that occupies the inter-blade spaces (Fig. 5B, C) and appears to be replacing the corroded variscite. This powder, which could not be pinpointed for a confident EDS analysis, is most likely the gibbsite shown by XRD analysis or, perhaps, berlinite.
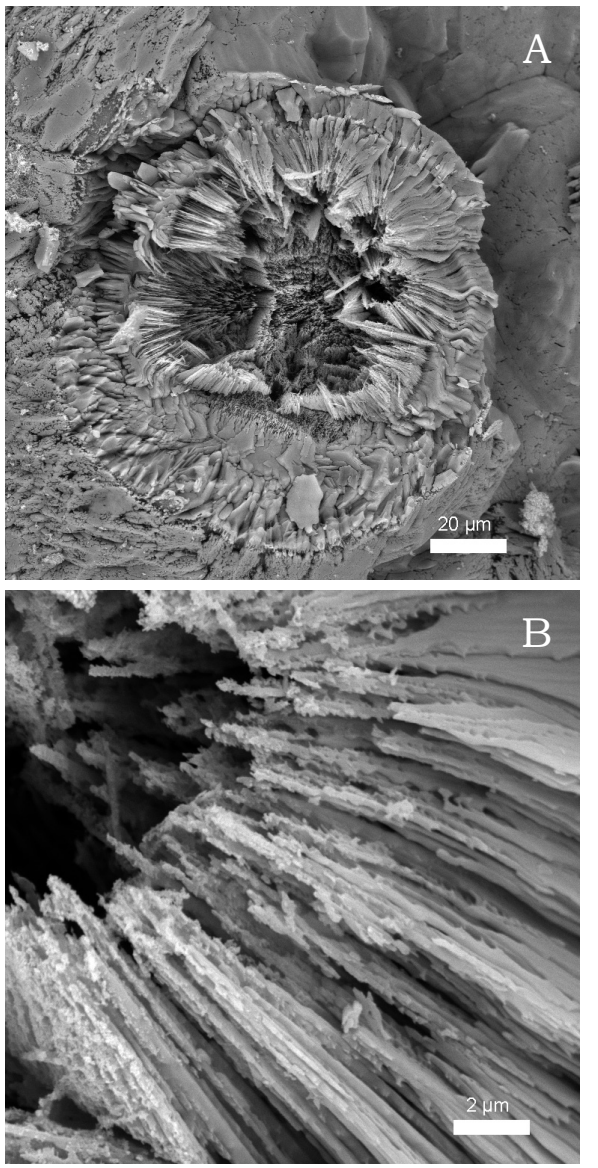

Fig. 4. A and B) Variscite globules or spherules viewed in section, revealing the internal structure of radiating blades.

The white material underneath the red variscite layer gave a clear XRD peak (Fig. 6, Table 2) of quartz, $\mathrm{SiO}_{2}$, with some components of berlinite, nitratine, $\mathrm{NaNO}_{3}$, calcite, $\mathrm{CaCO}_{3}$, and chrysotile, $\mathrm{Mg}_{3}\left[\mathrm{Si}_{2} \mathrm{O}_{5}\right](\mathrm{OH})_{4}$. Note that in this case (in contrast to the variscite sample above) the software did identify quartz, and, although it also identified berlinite, here the peaks centered on 21.02 and $26.79^{\circ} 2 \theta$ perhaps cannot be clearly be distinguished from the quartz peaks at 20.85 and $26.65^{\circ} 2 \theta$.

SEM analysis showed that the material is largely made up of a loose powder (Fig. 7). EDS analysis on this yielded only $\mathrm{O}$ and $\mathrm{Si}$, in proportions consistent with pure silica. The powder consists of tiny particles (Fig. 7A), some $100 \mathrm{~nm}$ in size (at the limit of resolution of our SEM). In places they appear to be organized into strings or domains (Fig. 7B, C) suggesting a colloidal structure (or potentially simply an artifact
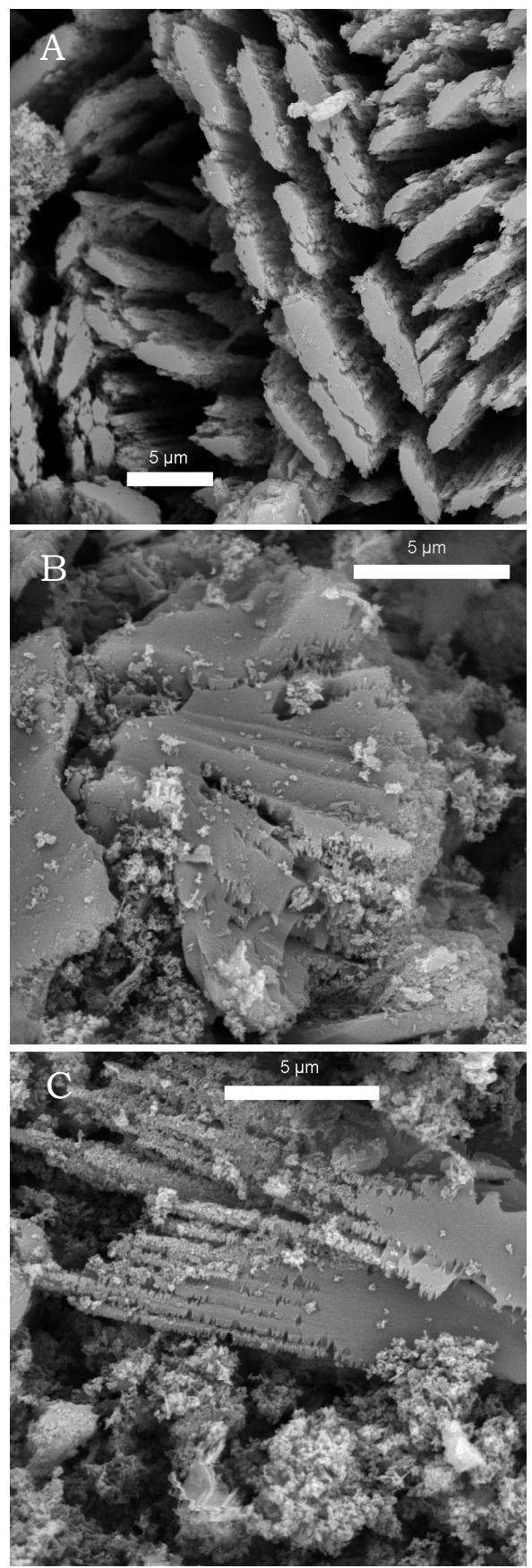

Fig. 5. Variscite being altered into, or replaced by, gibbsite or berlinite powder. A) Surface view showing expansion of the inter-crystallite spaces. B and C) Internal view of the variscite blades in various stages of alteration.

of drying). Although the SEM images are similar to many published of amorphous silica (e.g., Musić et al., 2011), the sharp XRD peak precludes both colloidal and amorphous silica. Therefore we identify this material as nano-particulate silica.

In summary, this Racer Cave deposit at the top of the guano is made up of an upper layer of red botryoidal/spherulitic variscite, some of which is slightly corroded/altered to gibbsite or berlinite, and an underlying layer of white nano-particulate silica.

\section{Niah Cave (Fluorapatite)}

Niah Cave contains extensive and deep deposits of stratified bat guano, dating through and beyond the radiocarbon age range of $>40,000$ years (Dykes, 2007). An exposure of the guano sequence, a vertical face created by guano mining, probably within the 


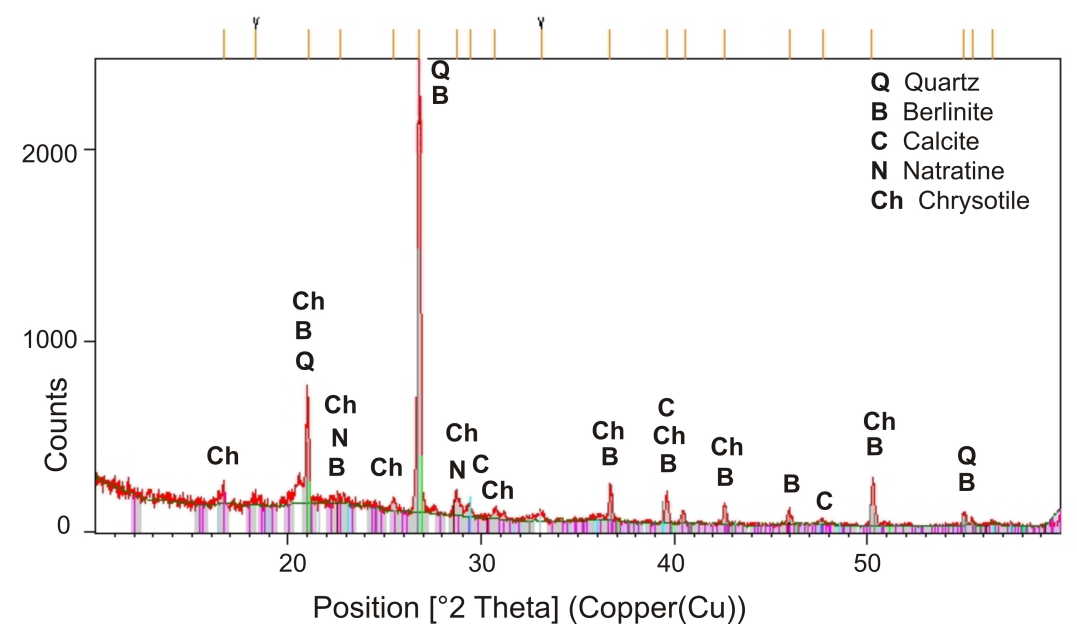

Fig. 6. XRD output from the white powder underneath the variscite layer in Racer Cave.

past 100 years, has developed a distinctive blue/green efflorescence (Fig. 8). XRD analysis (Fig. 9, Table 3) demonstrates that the material is fluorapatite, $\mathrm{Ca}_{5}\left(\mathrm{PO}_{4}\right)_{3 \mathrm{~F}}$, along with gypsum, and niter, $\mathrm{KNO}_{3}$. The bright blue color comes from the fluorapatite, the other components being white.

SEM analysis shows a fine powder overlying and interspersed with tabular/platy/foliated crystals (Fig. 10). EDS analysis of the powder, composed mainly of $\mathrm{O}, \mathrm{P}$, and $\mathrm{Ca}$, is consistent with the composition of fluorapatite but with very small components of clay minerals or silicate minerals, indicated by tiny amounts of $\mathrm{Na}, \mathrm{Al}, \mathrm{Si}, \mathrm{Cl}$, and $\mathrm{Fe}$. The powder lies between and over the crystals (Fig. 10A, B). The fluorapatite powder is very delicate, burning very soon after the electron beam hits it, and transforming into amorphous clouds. The images at higher power (e.g., Fig. 11A) are necessarily of low quality because they had to be taken as rapidly as possible. The powder

Table 2. XRD data for white powder underneath variscite layer in Racer Cave.

\begin{tabular}{|c|c|c|c|c|}
\hline Pos. $\left[{ }^{\circ} 2 \theta\right]$ & $\begin{array}{c}\text { Height } \\
\text { [cts] }\end{array}$ & $\begin{array}{c}\text { FWHM } \\
\text { Left }\left[{ }^{\circ} 2 \theta\right]\end{array}$ & $\begin{array}{c}\text { d-spacing } \\
\text { [Å] }\end{array}$ & $\begin{array}{c}\text { Rel. Int. } \\
\text { [\%] }\end{array}$ \\
\hline 16.65 & 91.20 & 0.1181 & 5.325 & 3.85 \\
\hline 18.32 & 31.50 & 0.6298 & 4.843 & 1.33 \\
\hline 21.03 & 552.01 & 0.1378 & 4.225 & 23.31 \\
\hline 22.69 & 25.96 & 0.4723 & 3.920 & 1.10 \\
\hline 25.44 & 52.88 & 0.2362 & 3.501 & 2.23 \\
\hline 26.79 & 2367.63 & 0.1771 & 3.327 & 100.00 \\
\hline 28.70 & 137.67 & 0.1574 & 3.110 & 5.81 \\
\hline 29.40 & 77.75 & 0.1574 & 3.038 & 3.28 \\
\hline 30.71 & 49.65 & 0.2362 & 2.911 & 2.10 \\
\hline 33.11 & 41.04 & 0.3149 & 2.706 & 1.73 \\
\hline 36.68 & 177.27 & 0.0984 & 2.450 & 7.49 \\
\hline 39.61 & 160.29 & 0.1968 & 2.275 & 6.77 \\
\hline 40.53 & 57.46 & 0.2362 & 2.226 & 2.43 \\
\hline 42.61 & 102.42 & 0.1574 & 2.122 & 4.33 \\
\hline 45.93 & 69.86 & 0.1968 & 1.976 & 2.95 \\
\hline 47.66 & 23.56 & 0.3149 & 1.908 & 1.00 \\
\hline 50.22 & 211.50 & 0.1968 & 1.817 & 8.93 \\
\hline 54.98 & 58.47 & 0.2362 & 1.670 & 2.47 \\
\hline 55.44 & 28.22 & 0.1574 & 1.657 & 1.19 \\
\hline 56.48 & 18.59 & 0.3936 & 1.629 & 0.79 \\
\hline
\end{tabular}

looks like nano-particles in most images, $\sim 500 \mathrm{~nm}$ long and $\sim 200 \mathrm{~nm}$ in diameter; they are revealed as six-sided crystals only in some of the highest magnification images. The arrangement of the nanocrystals has a suggestion of order, such as in biofilm, with domains of attached nano-crystals in strings and curved pouches like alveoli (Fig. 10C).

The large platy crystals proved to be gypsum, with EDS analysis showing O, $\mathrm{S}$, and $\mathrm{Ca}$ as the only components, in proportions consistent with gypsum. The micro-scale morphology of the crystals (tabular crystals, breaking up into flakes, Fig. 10C) mirrors macro-scale crystals of gypsum or anhydrite blades fragmenting at the edges into delicate fibers (e.g., they
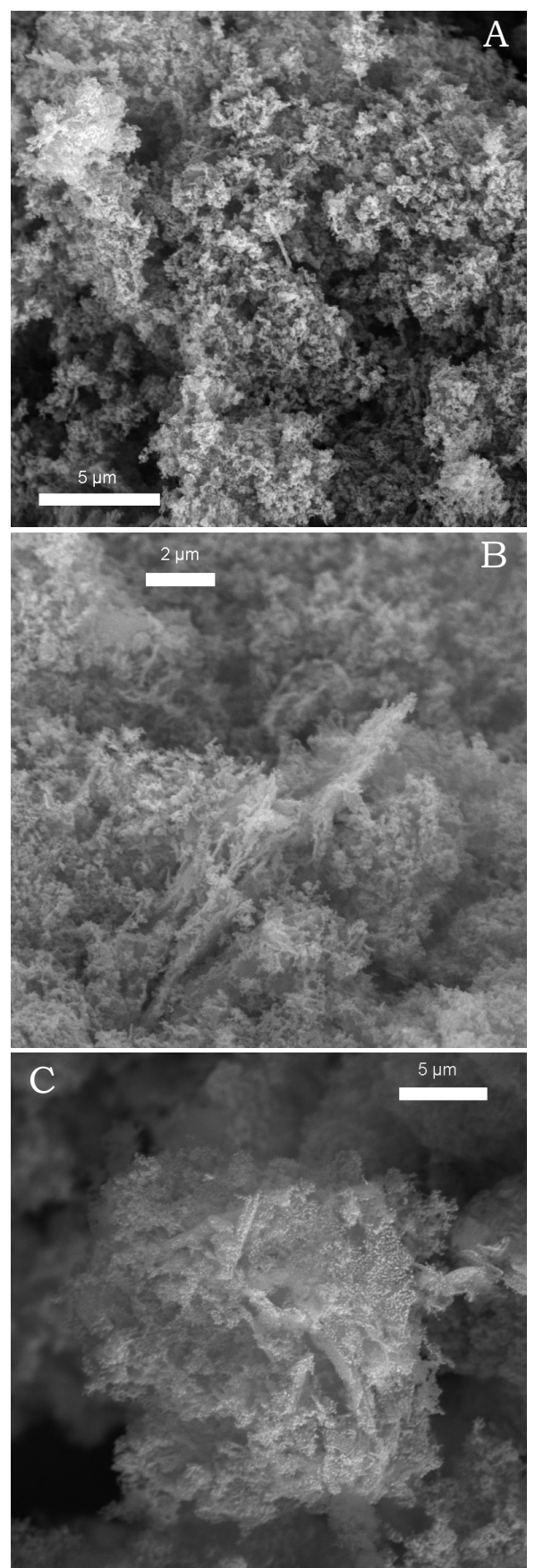

Fig. 7. A, B, and C) Three SEM images of the white powder, nanoparticulate silica, underneath the variscite layer in Racer Cave. 


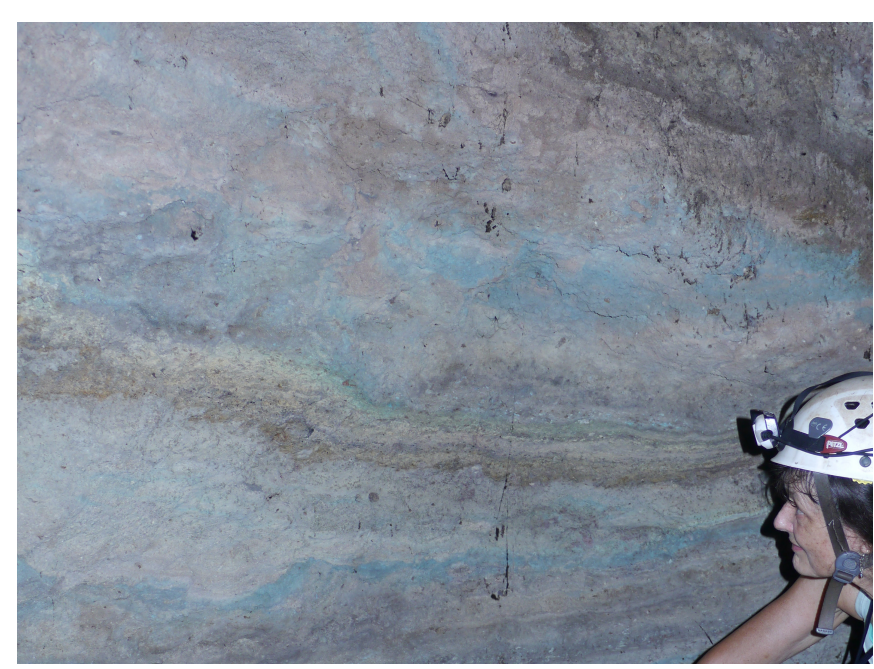

Fig. 8. Blue efflorescence of fluorapatite on the vertical face of guano exposed by mining, Niah Cave.

are very similar to the gypsum/anhydrite crystals depicted in Oliveira, 2013, or in Rauh \& Thuro, 2006, or in http:/ / publications.iodp.org).

This sample showed ample evidence of bacterial colonization of the surfaces of much of the gypsum. Rod-shaped bacteria (bacilli) can be seen occupying rod-shaped depressions in the surface of the crystal (Fig. 11A-C). It is not clear from the SEM images whether the bacilli are directly involved in the precipitation of the fluorapatite.

No niter was detected in the surfaces visible to SEM.

\section{DISCUSSION}

Variscite has been reported from multiple caves, and is associated with guano decomposition (Hill \& Forti, 1997; Onac et al., 2004). Acidic, phosphaterich solutions released from the guano by microbial action react with aluminum-rich clays present as underlying fluvial sediments or cave dust, to produce the hydrated aluminum phosphate. The Racer Cave sample shows no evidence of bacteria under SEM, suggesting that the variscite develops from simple chemical/evaporation processes. Absent the bat colony, strong airflow generates evaporation and a chromatographic, upward-wicking effect in the drying guano mass. The result is the sequential deposition of minerals in order of solubility, the less soluble silica, followed by the more soluble variscite. The alteration to gibbsite would then be a secondary process. The physical evidence of alteration and replacement of variscite suggests that the deposit may be short-lived.

Berlinite is a rare mineral in cave contexts, known only from Cioclovina Cave in Romania (Onac \& White, 2003; Onac \& Effenberger, 2007). In metamorphic and synthetic contexts, berlinite is a high-temperature mineral developing at temperatures above $550^{\circ} \mathrm{C}$ (Onac et al., 2007), leading these authors to infer spontaneous combustion of the guano deposit in Cioclovina Cave. The presence of berlinite as an efflorescence in the moist tropical environment of Racer Cave is incompatible with the combustion hypothesis. While our XRD analysis is strongly suggestive of the presence of berlinite in Racer Cave (and therefore the second reported occurrence of this mineral in a cave situation), the evidence is perhaps

Table 3. XRD data for Niah Cave mineral.

\begin{tabular}{|c|c|c|c|c|}
\hline Pos. $\left[{ }^{\circ} 2 \theta\right]$ & $\begin{array}{c}\text { Height } \\
\text { [cts] }\end{array}$ & $\begin{array}{c}\text { FWHM } \\
\text { Left }\left[{ }^{\circ} 2 \theta\right]\end{array}$ & $\begin{array}{c}\text { d-spacing } \\
\text { [Å] }\end{array}$ & $\begin{array}{c}\text { Rel. Int. } \\
\text { [\%] }\end{array}$ \\
\hline 11.86 & 2234.98 & 0.1181 & 7.461 & 100.00 \\
\hline 20.95 & 494.77 & 0.1181 & 4.240 & 22.14 \\
\hline 23.61 & 530.95 & 0.1574 & 3.769 & 23.76 \\
\hline 26.10 & 155.81 & 0.1181 & 3.414 & 6.97 \\
\hline 28.32 & 46.11 & 0.1968 & 3.151 & 2.06 \\
\hline 29.31 & 956.60 & 0.1574 & 3.048 & 42.80 \\
\hline 31.33 & 137.90 & 0.1574 & 2.855 & 6.17 \\
\hline 31.94 & 462.78 & 0.1181 & 2.802 & 20.71 \\
\hline 32.36 & 228.47 & 0.0984 & 2.766 & 10.22 \\
\hline 33.04 & 265.80 & 0.1378 & 2.711 & 11.89 \\
\hline 33.55 & 157.03 & 0.1378 & 2.671 & 7.03 \\
\hline 34.25 & 98.31 & 0.1968 & 2.619 & 4.40 \\
\hline 39.92 & 99.58 & 0.1968 & 2.259 & 4.46 \\
\hline 40.81 & 141.35 & 0.1181 & 2.211 & 6.32 \\
\hline 46.77 & 105.77 & 0.1771 & 1.942 & 4.73 \\
\hline 48.02 & 213.31 & 0.0984 & 1.895 & 9.54 \\
\hline 48.61 & 65.13 & 0.1574 & 1.873 & 2.91 \\
\hline 49.63 & 130.97 & 0.2755 & 1.837 & 5.86 \\
\hline 50.51 & 135.69 & 0.1181 & 1.807 & 6.07 \\
\hline 51.33 & 104.24 & 0.1968 & 1.780 & 4.66 \\
\hline 56.87 & 95.21 & 0.0984 & 1.619 & 4.26 \\
\hline
\end{tabular}

not conclusive. However, we argue that the absence of evidence for burning does not necessarily preclude the presence of berlinite. We suggest that in the Racer Cave situation, berlinite is almost certainly the product of microbial biochemical reactions on the surface of the parent variscite crystals, transforming to berlinite by loss of water. Similarly, we interpret the Racer Cave gibbsite, previously reported in association with guano in Green Cave, Malaysia (Laverty, 1982) to be a decomposition product of variscite. This interpretation is consistent with the observations of Banfield et al. (1999) who report that

Figure 9. XRD spectra, Niah Cave fluorapatite-gypsum-niter.

F Fluorapatite N Niter

50 

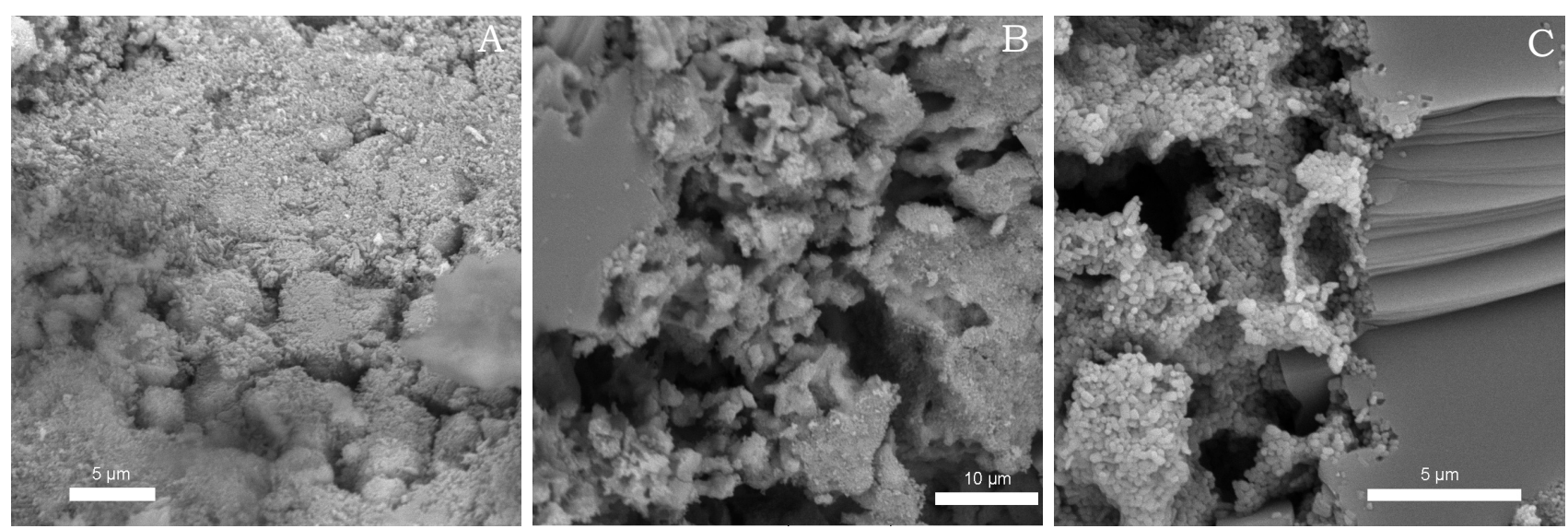

Fig. 10. SEM images of the blue powder (fluroapatite on gypsum) from Niah Cave. A) Fluorapatite powder coating crystals of gypsum, viewed from above; B) Detail of disposition of fluorapatite powder occupying interstices between crystals; C) Side view showing the tabular nature of the gypsum crystals (to the right), with flaking on the broken exposed edge, and intricate patterns of dissolution on the inner edge. The fluorapatite powder (to the left) is arranged in alveolar-like domains reminiscent of biofilms.
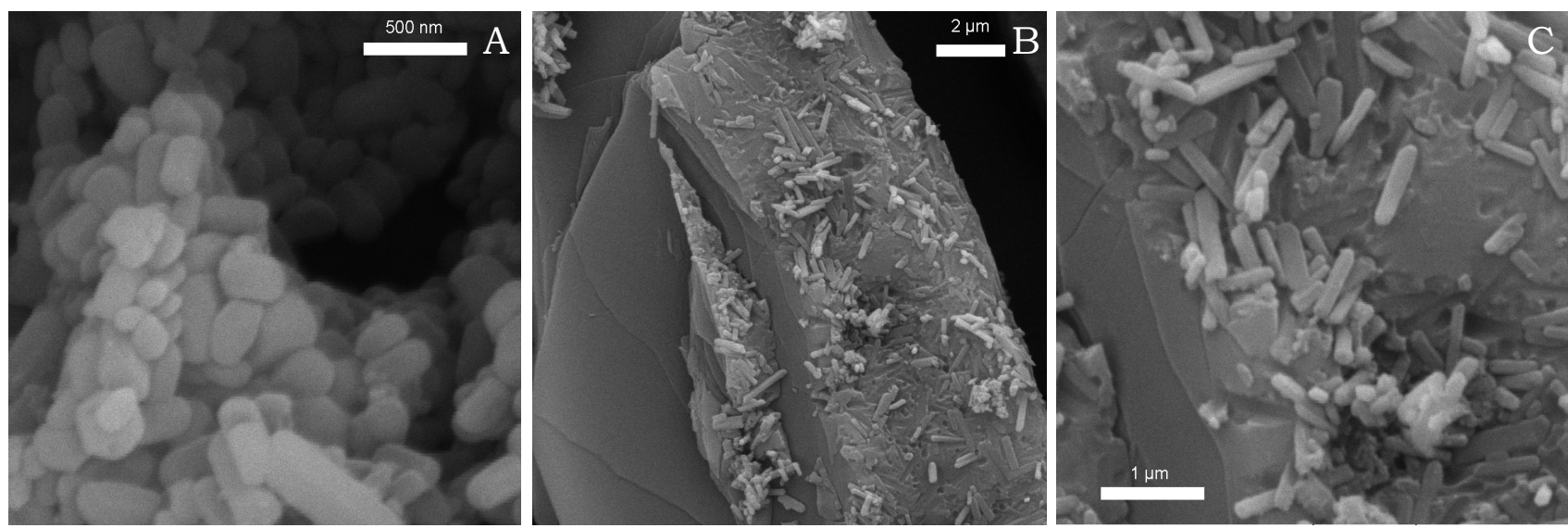

Fig. 11. SEM images of the blue fluorapatite powder. A) Higher magnification shows that some of the particles can be resolved as six-sided crystals; B) Gypsum crystal showing bacterial coating with many rod-shaped depressions on the surface which conform to the size and shape of the bacilli ( 1.5 micron in length); C) Detail of image B, showing the darker grey, elongate, bacilli and the paler-colored, smaller, fragments of fluorapatite powder.

microbes contribute to enhanced dissolution of insoluble secondary phosphates, possibly by release of organic acids. Banfield et al. (1999) also report that variscite is microbially precipitated. Redox conditions are important: Wisawapipat et al. (2017) observed that gibbsite was transformed into variscite during soil reduction, and back-transformed during soil reoxidation. These varying conditions can be expected to occur during the transition from water-saturated, anaerobic guano beneath an active roost to dry, more aerobic conditions in relict guano deposits and the efflorescence of phosphate minerals into a fully aerobic cave atmosphere.

Silica has been reported (as quartz) from a number of bat guano deposits in peninsula Malaysia, Borneo, and the Philippines (Wurster et al., 2015). Amorphous silica was reported by Pogson et al. (2014) from the Jenolan caves, Australia, where it was attributed to the breakdown of guano. No publications could be found reporting nano-particulate silica in caves, although many studies have been done of such material in other natural systems. Tobler et al. (2009) report that silica nano-particulate formation in natural systems generally starts with silica polymerization and nucleation, followed by particle growth and "ripening", and, finally, particle aggregation. The maximum particle size is about $8 \mathrm{~nm}$. They also report that in most natural waters nano-particles do not form because aggregation tends to occur before the ripening stage.

The ultimate source of this silica is unknown, although, noting that other accounts of amorphous silica in the literature all relate to biogenic precursors such as cow dung, or corn husks, e.g., Rani et al. (2014), it is likely to be simply part of the geochemical cycling. Silica is a normal component of plant tissue (especially grasses), occurring in the form of hydrated condensates of orthosilicic acid, $\mathrm{Si}(\mathrm{OH})_{4}$ linked to biomolecules (Smis et al., 2014). Most plants have up to $2 \%$ Si (by dry weight) but Smis et al. (2014) report a maximum of $7.8 \%$ in horsetails. This plant-sourced silica would be passed through the food chain up to and through the bats, and thereby disseminated in the guano.

Fluorapatite is known from several other cave localities, e.g., Slaughter Canyon Cave, New Mexico (Hill \& Forti, 1997), and Lighthouse Cave, Bahamas (Onac et al., 2001), where it is invariably associated with guano or fossil bone deposits. The origin of the fluorine in bat guano has not been previously investigated, but it has been reported as a significant component of ornithogenic soils such as those associated with penguin rookeries (Tatur, 1987), where it complexes with calcium phosphates, and as a constituent of Peruvian bird guano (Hutchinson, 1950). Fluorine is not homeostatically regulated 
in mammals (Buzalaf and Whitford, 2011) but is excreted primarily in urine (Massman, 1981) and absorbed into bone by substitution of $\mathrm{F}^{-}$for $\mathrm{OH}^{-}$in the hydroxylapatite matrix (Bertonia et al., 1988). Mammalian bone can be a significant accumulator of environmental fluorine; in humans, fluorine content of bone increases linearly with age at a rate of 0.08 $\pm 0.01 \mathrm{mg} \mathrm{F} / \mathrm{g}$ of $\mathrm{Ca}$ per year (McNeill et al., 2016). Long-lived mammals such as bats (e.g., Tadarida brasiliensis, a sister species to Chaerephon plicatus at Niah and Mulu, lifespan 10 years; Brunet-Rossinni $\&$ Austad, 2004; Weigl, 2005) have ample opportunity to accumulate fluorine. Some plants are known accumulators of fluorine, e.g., tea (Camellia sinensis), where levels of $1243 \pm 573 \mathrm{mg} \mathrm{F} / \mathrm{kg}$ dried, freshlyharvested leaves of tea have been recorded (Lu et al., 2004). Fluorine in plant tissues would be passed to herbivorous insects. Fluorine concentrations in insect chitin have not been explicitly studied, but can be expected to be low since the ions would not be retained by the N-polysaccharide matrix. However, fluorine in insect tissues would be absorbed onto bat bone and excreted in bat urine. The appearance of fluorapatite in the post-mining excavation of old, dry guano at Niah, long after exposure to significant quantities of bat urine, suggests that the original source is bioaccumulated fluorine in the abundant bat bone of the deposit.

The presence of niter in the Niah guano deposit is expected. Fresh Free-tailed bat (Chaerephon plicatus) guano from Deer cave, Mulu contains 7.6\% nitrogen, which is progressively released in acidic solution by microbial decomposition (McFarlane et al., 2017). Although at least 11 nitrate mineral species are known from guano-associated cave deposits (Hill \& Forti, 1994), most are highly deliquescent and only niter can crystallize at relative humidities of $85 \%$ or higher (Hill, 1981) and are thus likely to occur in caves of the moist tropics.

\section{ACKNOWLEDGEMENTS}

We thank Datu Haji Len Talif Salleh and his staff at the Sarawak Forestry Department for permission to collect samples from the caves of Mulu and Niah (permit NPW.907.4.4(v)-58). Park managers Brian Clark and Hein Gerstner (Mulu) and Shirley ak Nathanael Naning (Niah) kindly supported and facilitated our fieldwork. Fieldwork was funded in part by grants from the National Science Foundation Grant (0952398) and the National Geographic Society (8437-08). We thank the anonymous reviewers for helpful insights.

\section{REFERENCES}

Banfield J.F., Barker W.W., Welch S.A. \& Taunton A., 1999 - Biological impact on mineral dissolution: Application of the lichen model to understanding mineral weathering in the rhizosphere. Proceedings of the National Academy of Sciences, 96 (7): 3404-3411.

Bertonia E., Bigia A., Cojazzib G., Gandolfia M., Panzavolta A. \& Roveria N., 1998 - Nanocrystals of magnesium and fluoride substituted hydroxyapatite.
Journal of Inorganic Biochemistry, 72 (1-2): 29-35. https://doi.org/10.1016/S0162-0134 (98)10058-2

Brunet-Rossini A.K. \& Austad S.N., 2004 - Ageing studies on bats: a review. Biogerontology, 5: 211-222.

https://doi.org/10.1023/B:BGEN.0000038022.65024.d8

Buzalaf M.A. \& Ehitford G.M., 2011 - Fluoride metabolism. Monographs in Oral Sciences, 22: 20-36.

https://doi.org/10.1159/000325107

Bird M.I., Boobyer E.M., Bryant C., Lewis H.A., Paz V. \& Stephens W.E. 2007 - A long record of environmental change from bat guano deposits in Makangit Cave, Palawan, Philippines. Earth and Environmental Science Transactions of the Royal Society of Edinburgh, 98: 59-69. https://doi.org/10.1017/S1755691007000059

Dykes A.P., 2007 - Mass movements in cave sediments: investigation of a 40,000-year old guano mudflow inside the entrance of the Great Cave of Niah, Sarawak, Borneo. Landslides, 4: 279-290.

https://doi.org/10.1007/s10346-006-0077-5

Hill C.A., 1981 - Mineralogy of cave nitrates. National Speleological Society Bulletin, 43 (4): 127-132.

Hill C.A. \& Forti P., 1997 - Cave minerals of the World $\left(2^{\text {nd }}\right.$ Ed.). National Speleological Society, Huntsville. 463 p.

Hutchinson G.E., 1950 - Survey of existing knowledge of biogeochemistry. 3, The biogeochemistry of vertebrate excretion. Bulletin of the American Museum of Natural History, 96: 1-554.

Laverty M., 1982 - Cave minerals in the Gunung Mulu National Park, Sarawak. Cave Science, 9 (2): 128-133.

Lu Y., Guo W.F. \& Yang X.Q., 2004 - Fluoride content in tea and its relationship with tea quality. Journal of Agricultural Food Chemistry, 52 (14): 4472-4476.

https://doi.org/10.1021/jf0308354

Massman W., 1981 - Reference values of renal excretion of fluorine. Journal of Clinical Chemistry and Clinical Biochemistry, 19: 1039-1041. https://doi.org/10.1515/cclm.1981.19.10.1039

McFarlane D.A., Lundberg J. \& van Rentergem G., 2017 - Preliminary observations on tropical bat caves as biogeochemical nitrogen sinks. Proceedings of the $17^{\text {th }}$ International Congress of Speleology, Penrith, 1: 157-160.

McNeill F.E., Mostafaei F., Pidruczyny A. \& Chettle D.R., 2016 - Correlation between fluorine content in tea and bone assessed using neutron activation analysis in a Canadian urban population. Journal of Radioanalytical and Nuclear Chemistry, 309: 389-395.

https://doi.org/10.1007/s10967-016-4749-x

Morris M.C., McMurdie H.F., Evans E.H., Paretzkin B., Parker H.S. \& Panagiotopoulos N.C., 1981 - Standard $X$-ray Diffraction Powder Patterns, Section 18-Data for 58 Substances. National Measurement Laboratory, National Bureau of Standards, Washington, DC 20234.

Musić S., Filipović-Vinceković N. \& Sekovanić L., 2011 - Precipitation of amorphous $\mathrm{SiO}_{2}$ particles and their properties. Brazilian Journal of Chemical Engineering, 28 (1): 89-94.

https://doi.org/10.1590/S0104-66322011000100011

Oliviera M., 2013 - Study of the degradation of 18th century alabaster sculptures through accelerated aging on test samples. CeROArt [Online], EGG 3, Online since 10 May 2013. http://ceroart.revues.org/3187.

Onac B.P. \& Effenberger H.S., 2007 - Re-examination of berlinite $\left(\mathrm{AlPO}_{4}\right)$ from the Cioclovina, Cave, Romania. American Mineralogist, 92: 1998-2001. https://doi.org/10.2138/am.2007.2581

Onac B.P. \& White W.B., 2003 - First reported sedimentary occurrence of berlinite $\left(\mathrm{AlPO}_{4}\right)$ in phosphate-bearing sediments from Cioclovina Cave, Romania. American Mineralogist, 88: 1395-1397.

https://doi.org/10.2138/am-2003-8-925 
Onac B.P., Effenberger H.S. \& Breban R.C., 2007 - Hightemperature and "exotic" minerals from the Cioclovina Cave, Romania: a review. Studia Universitatis BabeşBolyai, Geologia, 52 (2): 3-10.

https://doi.org/10.5038/1937-8602.52.2.1

Onac B.P., Mylroie J.E. \& White W.B., 2001 - Mineralogy of cave deposits on San Salvador Island, Bahamas. Carbonates and Evaporites, 16 (1): 8-16. https://doi.org/10.1007/BF03176222

Onac B.P., Kearns J., Breban R. \& Cîntă Pânzaru S., 2004 - Variscite $\left(\mathrm{AlPO}_{4} \cdot 2 \mathrm{H}_{2} \mathrm{O}\right)$ from Cioclovina Cave (Şureanu mountains, Romania): a tale of a missing phosphate. Studia UBB, Geologia, 49 (1): 3-14. https://doi.org/10.5038/1937-8602.49.1.1

Peck S.B. \& Kukalova-Peck J., 1981 - The subterranean fauna and conservation of Mona Island (Puerto Rico): A Caribbean karst environment. Bulletin of the National Speleological Society, 43 (3): 59-68.

Pogson R.E., Osborne R.A.L. \& D.M. Colchester, 2014 Minerals of Jenolan Caves, New South Wales, Australia: Geological and biological interactions. Proceedings of the Linnean Society of New South Wales, 136: 1-18.

Rani K.M., Palanisamy P.N. \& Sivakumar P., 2014 Synthesis and characterization of amorphous nanosilica from biomass ash. International Journal of Advanced Technology in Engineering and Science, 2 (10): 71-76.

Rauh F. \& Thuro K., 2006 - Why do pure anhydrites differ in their swelling capacity? 3rd Colloquium Rock Mechanics - Theory and Practice. Mitteilungen für Ingenieurgeologie und Geomechanik, 7: 191-204.

Shahack-Gross R., Berna F., Karkanas P. \& Weiner S., 2004 - Bat guano and preservation of archaeological remains in cave sites. Journal of Archaeological Science, 31: 1259-1272.

https://doi.org/10.1016/j.jas.2004.02.004

Smis A., Ancin Murguzur F.J., Struyf E., Soininen E.M., Herranz Jusdado J.G., Meire P. \& Bråthen K.A., 2014 -
Determination of plant silicon content with near infrared reflectance spectroscopy. Frontiers in Plant Sciences, 5: 496. https://doi.org/10.3389/fpls.2014.00496

Tatur A., 1987 - Fluorine in ornithogenic soils and minerals on King George Island, West Antarctica. Polish Polar Research, 8 (1): 65-74.

Tobler D.J., Shaw S., \& Benning. L.G. 2009 Quantification of initial steps of nucleation and growth of silica nanoparticles: An in-situ SAXS and DLS study. Geochimica et Cosmochimica Acta, 73 (18): 5377-5393. https://doi.org/10.1016/j.gca.2009.06.002

Weigl R., 2005 - Longevity of mammals in captivity; from the living collections of the World. Kleine SenckenbergReihe, 48: Stuttgart.

Wisawapipat W., Charoensri K., \& Runglerttrakoolchai J., 2017 - Solid-phase speciation and solubility of phosphorus in an acid sulfate paddy soil during soil reduction and reoxidation as affected by oil palm ash and biochar. Journal of Agricultural Food Chemistry, 65 (4): 704-710.

https://doi.org/10.1021/acs.jafc.6b03925

Wurster C.M., McFarlane D.A., Bird M.I., Ascough P. \& Athfield N.B., 2010a - Stable isotopes of subfossil bat guano as a long-term environmental archive: insights from a Grand Canyon cave deposit. Journal of Cave and Karst Studies, 72: 111-121.

https://doi.org/10.4311/jcks2009es0109

Wurster C.M., Munksgaard N., Zwart C. \& Bird M., 2015 The biogeochemistry of insectivorous cave guano: a case study from insular Southeast Asia. Biogeochemistry, 124 (1-3): 163-175.

https://doi.org/10.1007/s10533-015-0089-0

Wurster C.M., Bird M.I., Bull I.D., Creed F., Bryant C., Dungait J.A. \& Paz V., 2010b - Forest contraction in north equatorial Southeast Asia during the Last Glacial Period. Proceedings of the National Academy of Sciences, 107: 15508-15511. https://doi.org/10.1073/pnas.1005507107 